\title{
MEASUREMENT-AND-ANALYTICAL SYSTEM FOR WELDING PARAMETERS AND NOISE LEVEL DURING PROCESS OF WELDED STRUCTURES MANUFACTURE
}

\author{
L. SZUBERT, P. SKOCZEWSKI, J. MATUSIAK and J. WYCIŚLIK
}

Institute of Welding

16-18 Str. Bl. Czeslawa, 44-100, Gliwice, Poland. E-mail: leszek.szubert@is.gliwice.pl

\begin{abstract}
This paper presents the design, technical possibilities and intended use of the multi-station measurement-analytical system for assessing welding process parameters and noise levels. The system is an innovative solution as regards the measurement technique related to welding parameters and acoustic pressure in production floors. Once implemented industrially, the system enables the monitoring and recording of noise levels in individual work centres as well as the monitoring and recording of technological conditions accompanying welding of various structures and products. 8 Ref., 1 Table, 9 Figures.
\end{abstract}

Keywords : noise level, acoustic, pressure, welding parameters, measurement and analytical system

The use of welding technologies in industrial practice entails the necessity of testing and determining conditions related to health and safety at work. Welding belong to manufacturing processes significantly and unfavourably affecting the work environment. Presently, welding along with allied techniques constitute the most developed and established joining technology used when making structures and products of diverse materials and sizes in many industrial sectors. Various welding methods generate excessive noise being a physical factor having a definitely destructive effect on the worker's physical health and significantly deteriorating work conditions.

The exposure of individual welding shop workers to noise depends on numerous factors, particularly including concurrent work performed in individual production centres, welding current and arc voltage parameters and the intensity of post-weld machining. The acoustic environment of a production floor where welded structures are made is hazardous to the worker's health and affects the efficiency of production. According to Instytut Spawalnictwa's research and experience, in many companies the excessive noise accompanying the making of welded structures constitutes a very urgent and important issue.

Having in view the foregoing, Instytut Spawalnictwa has developed an innovative measurement-analytical system for measuring and analysing welding process parameters and noise levels in technological floors [1]. The combination of measuring and recording functions of the system with analytical modules related to the making of welded structures and concerning acoustic conditions is an innovative solution enabling the control of manufacturing (welding) processes and that of the acoustic environment of work.
Outline of the system. In strict terms, the system is by definition a computer-based control-measurement, measurement-analytical and analytical-advisory system. The measurement system is an appropriately organised set of elements constituting a certain whole dedicated to obtaining measurement information from an object being tested and providing the user with this information in a usable form. The control system is tasked with verifying whether a measurement result is restricted within a certain range of boundary values. In turn, the role of the analytical system is to analyse collected information and enable the user to draw logical and practical conclusions. The advisory (expert) system, on the basis of collected information and using an appropriate algorithm, provides the user with a solution to a given problem. The term «computer-based» means that all of the functions enumerated above are performed using a computer system.

The system is composed of two layers, i.e. hardware and software. The hardware layer includes sensors, data acquisition cards, communication interface cards, computer system elements as well as the remaining elements, systems and electronic devices. The software layer includes software modules controlling the operation of the measurement system as well as software modules implementing the adopted functionality of the control-measurement system and the adopted functionality of the analytical-advisory system.

According to a previously adopted assumption, the system is not dedicated to a specific type of welding station. It has been assumed that the system should be usable with many different types of welding stations. For this reason, the system architecture is sufficiently open and versatile so that the system could be used in various conditions. The multi-station character of the system means that system func- 
tions are implemented on many welding stations at the same time.

The system is experimental in nature and constitutes an innovative approach to the assessment of sounds emitted when welded structures are made in a production shop. The system incorporates the control-measurement functions of the system with analytical functions related to the making of welded structures and to acoustic conditions, as well as analytical-advisory functions aimed to reduce the level of sound by changing welding process parameters.

Functional description of the system. The system is relatively complex and its functionalities can be viewed in various ways [1]. The most general level involves the following functions:

- measuring/recording - acquisition of parameters connected with welding processes and parameters related to noise generated and emitted during production;

- storing (archiving) — transfer of recorded data from welding stations and data collected during acoustic measurements to the central storage unit (database server), where these data are stored and secured;

- analytical - analysis of collected data, calculating derivative quantities, the evaluation of welding processes and the assessment of noise levels;

- advisory - changes of technological parameters aimed to reduce noise levels;
- visualising - presentation of collected data.

The detailed description and characteristics of system functions are presented in the Table.

System architecture. The system can be characterised as a distributed multi-station analytical-measurement system connected (via a computer network) with a central computer (server) storing recorded parameters and data created on the basis of these parameters (Figure 1). The data can be accessed by users connected to the computer network and provided with appropriate software applications enabling the users to visualise and analyse collected information [2].

The system represents a typical example of client/ server network architecture, where the central computer with the database (server) are the receiver of data generated by measurement modules installed at production stations and analytical software (clients) used by the main system users, i.e. welding technologists, health and safety inspectors and other personnel managing production processes.

The measurement system is composed of modules for measuring welding parameters (Figure 2), provided with three measurement channels, i.e. for measuring welding current, arc voltage and wire feed rate. The modules have been provided with appropriate measuring transducers, measurement cards and an industrial controller controlling the operation of the measurement module provided with an output for communication via Ethernet.

Description of functions of the system for measuring and analysing welding parameters and noise when making welded structures [1]

\begin{tabular}{|c|c|c|}
\hline Function & Description & Advantages \\
\hline $\begin{array}{l}\text { Recording of welding } \\
\text { parameters }\end{array}$ & $\begin{array}{l}\text { Measurement of quantities related to arc welding processes } \\
\text { (MIG/MAG), i.e. welding current, arc voltage and wire feed rate }\end{array}$ & $\begin{array}{l}\text { Possibility of obtaining detailed } \\
\text { technological information on } \\
\text { welding processes }\end{array}$ \\
\hline $\begin{array}{l}\text { Recording of noise } \\
\text { parameters }\end{array}$ & Recording of acoustic pressure levels using correction $(A, C)$ & $\begin{array}{c}\text { Possibility of obtaining detailed } \\
\text { information on noise present at } \\
\text { selected production stations }\end{array}$ \\
\hline $\begin{array}{l}\text { Archiving of recorded } \\
\text { parameters }\end{array}$ & Saving of recorded parameters in the database & $\begin{array}{c}\text { Possibility of using data for further } \\
\text { analysis and documentation } \\
\text { of production processes }\end{array}$ \\
\hline $\begin{array}{l}\text { Automated information } \\
\text { collection process }\end{array}$ & $\begin{array}{l}\text { Recording, saving and processing of selected parameters are } \\
\text { performed automatically by the measurement system }\end{array}$ & $\begin{array}{l}\text { Unattended gathering of informa- } \\
\text { tion on production processes }\end{array}$ \\
\hline $\begin{array}{l}\text { Visualisation and reporting } \\
\text { of collected data }\end{array}$ & $\begin{array}{l}\text { Presentation of collected information, recorded waveforms, } \\
\text { calculated derivative quantities in various timeframes (shift, } \\
\text { daily, monthly etc.) enables the system user to assess the process } \\
\text { production in a bigger picture. } \\
\text { Generation of daily, weekly etc. reports }\end{array}$ & $\begin{array}{l}\text { Assessment and detection } \\
\text { of trends and untypical changes } \\
\text { of parameters }\end{array}$ \\
\hline $\begin{array}{l}\text { Analytical-advisory } \\
\text { function for correlation of } \\
\text { welding parameters and } \\
\text { sound levels }\end{array}$ & $\begin{array}{c}\text { On the basis of defined technological welding parameters it is } \\
\text { possible to select/adjust an alternative set of parameters leading } \\
\text { to the reduction of noise generated and emitted during } \\
\text { production processes }\end{array}$ & $\begin{array}{l}\text { Reduction of noise improving } \\
\text { work conditions }\end{array}$ \\
\hline System scalability & $\begin{array}{l}\text { Universal module design of the system makes it possible to add } \\
\text { more stations to the system and to add new functions connected } \\
\text { with the analysis of collected data without reorganising the system }\end{array}$ & $\begin{array}{l}\text { Module architecture of the system } \\
\text { enabling its easy extension }\end{array}$ \\
\hline $\begin{array}{l}\text { Access via a computer } \\
\text { network }\end{array}$ & $\begin{array}{l}\text { Use of Ethernet for data transmissions. The possibility of } \\
\text { incorporating the system into the network infrastructure of the } \\
\text { production facility. As a result, collected data are available to all } \\
\text { authorised workers using the computer network }\end{array}$ & Availability of the system \\
\hline
\end{tabular}


The operation of the measurement module is entirely autonomous. Its software automatically detects the commencement of welding process and afterwards, on the basis of momentary values, calculates systematically the average and root-mean-square values of recorded waveforms and sends this information to the server via the computer network.

The module for measuring noise intensity is presented in Figure 3. The system includes DSA-50 noise meter manufactured by Sonopan, provided with special software adjusted to the welding measurement system. The meter is equipped with special RS-232 digital output for communication with the master system. For this reason, the module is equipped with an RS-232/Ethernet converter to enable communication between the meter and the server via the computer network.

Measurement-analytical system software. Because of the complex functionality of the system and due to the fact that the system has been created by many developers using various IT and measurement technologies, the system software has been divided into the following independent modules (applications) $[5,6]$ :

- monitor of parameters in the production floor software for the visualisation of welding parameters and noise levels currently recorded at monitored production stations available in the production shop;

- software for the visualisation of collected data - presentation of collected data and calculated derivative quantities saved in the database, activated remotely by any computer connected to the computer network (e.g. from the office of welding technologist/health and safety inspector);

- analytical-advisory module for the correlation of welding conditions and noise levels (activated remotely, e.g. from the office of welding technologist/health and safety inspector);

- reporting software - generation of periodical reports on the basis of collected data stored in the database;

- software of recorders - software of measurement modules for recording welding parameters and the software of noise meters for recording noise level parameters.

The module structure has made it possible to implement required functions of the system, independently in individual modules, using the computer network for the

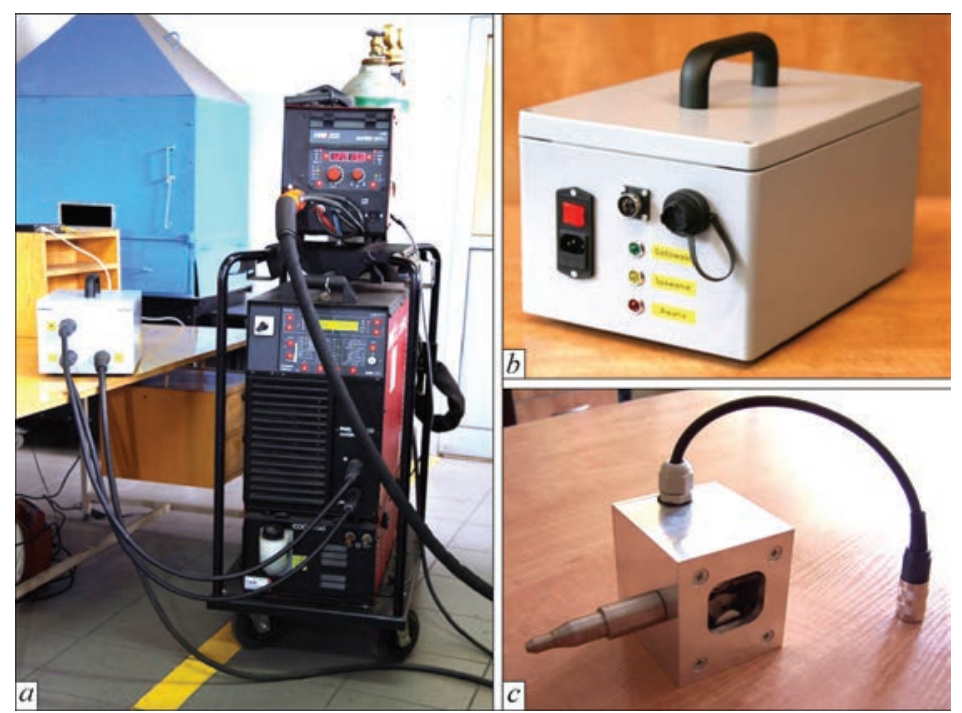

Figure 2. Module for measuring technological parameters of welding processes [1-3]: $a$ - module connected to welding power source; $b$ - measurement module; $c$ - transducer for measurements of filler wire feed rate installed in the feeder 


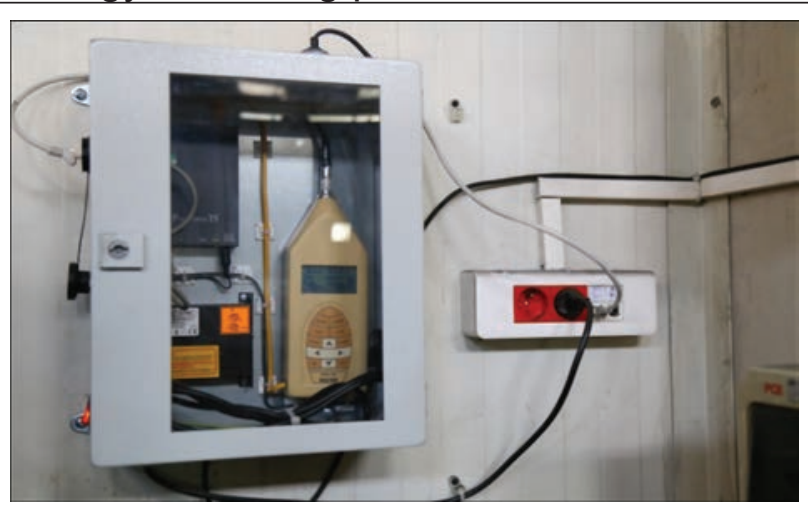

Figure 3. Noise meter in the production floor

characteristic $A$. The panel 3 of the analyser displays equivalent 1 -second levels of acoustic pressure $A$ for individual octaves. In addition to the panels enumerated above, the bookmark also contains the panel of configuration presenting the current configuration of noise meter and the panel of calibration presenting the information on the timing of the meter recent calibration. comparison of noise level values indicated by all $5 \mathrm{~m}$ :

- $L_{\text {Aeq1s }}$ - equivalent $A$-weighted sound pressure level over 1-second duration; level,

- $L_{\mathrm{ASmx}}-$ maximum $A$-weighted sound pressure

- $L_{\mathrm{Cpk}}$ - peak $C$-weighted sound pressure level,

- $L_{\text {AeqT }}$ - equivalent $A$-weighted sound pressure level over duration $T$ (calculated since the start of the shift until the present moment).

The welding parameter monitor interface of a selected meter is presented in Figure 6. The programme window contains the panel of graphs presenting waveforms of welding current and arc voltage (also root-mean-square current and root-means-square voltage) as well as wire feed rate recorded during
The bookmark List is used for the simultaneous

welding. The control lights in the panel of parameters provide the following information (on an ongoing basis): root-mean-square values of welding current and voltage, average filler wire feed rate, welding start time, and welding process duration.

The bookmark List contains simple welding log in the form of table displaying the number of recently made welds. The log contains the following fields: meter number, welding start time, welding process duration, average welding current, root-mean-square welding current, average arc voltage, root-meansquare arc voltage, and average wire feed rate.

The primary function of the programme is to preview present measurement results and archived data (Figure 7). The programme window contains three graphs, namely welding current, arc voltage and filler wire feed rate (average). The window also contains the panel allowing the selection of work shift and measurement date as well as the table containing information related to selected measurement such as date when the given weld was made, recording date, welding process duration and values of individual quantities being measured. In the graphs presented below, successive points correspond to average values of successively made welds. Clicking on any point opens the window containing time series plots of recorded parameters related to selected weld.

Figure 8 presents the programme window for the visualisation of acoustic pressure measurement results. The window contains graphs showing changes of acoustic pressure for each work shift, the table containing measurement results in the form of numeric values, and the panel for selecting measurement results. The window displays the following acoustic pressure values:

- $L_{\text {Aeq, } 1 \mathrm{~m}}$ - equivalent 1-minute level of acoustic pressure corrected according to frequency characteristic $A$;

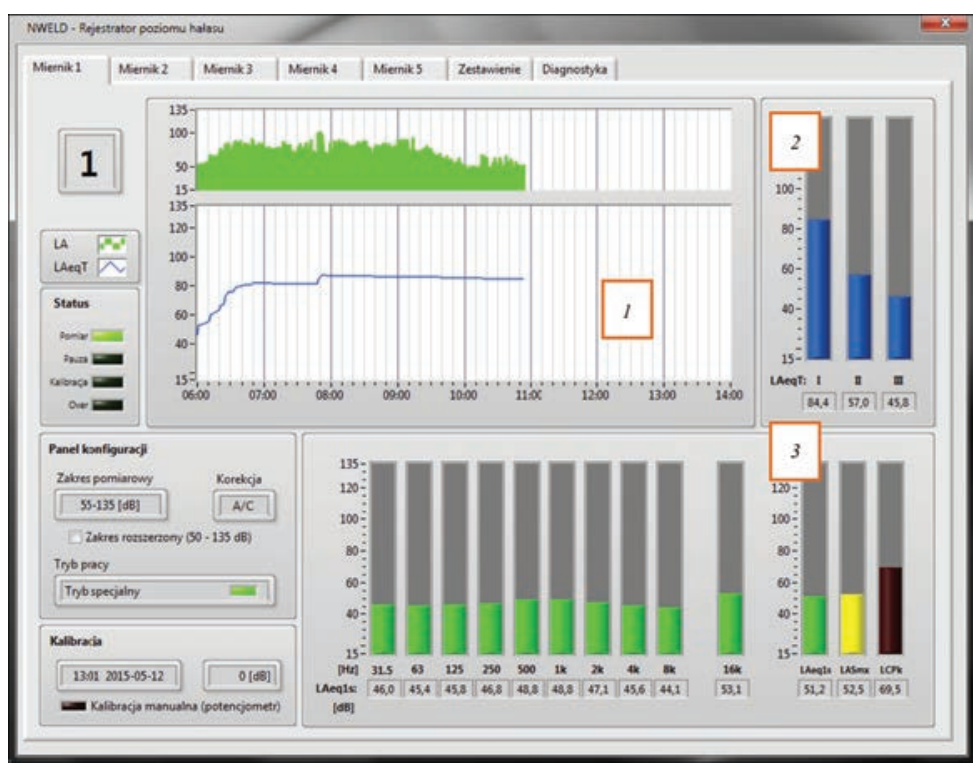

- $L_{\mathrm{ASmx}, 1 \mathrm{~m}}$ - maximum 1-minute rootmean-square value of acoustic pressure;

- $L_{\mathrm{Cpk}, 1 \mathrm{~m}}$ - maximum momentary value of acoustic pressure, recorded in the 1-minute period, corrected according to frequency characteristic $C$.

An exemplary window of the analytical-advisory module for the correlation of noise levels and welding parameters is presented in Figure 9. The primary function of the module is to provide the possibility of predicting acoustic pressure values on the basis of developed statistical model. The model is based on multiple regression and describes the dependence of noise generated during the welding of sheets on factors having statistically significant effect on the level of noise. On the basis of research-re-

Figure 4. Monitor of acoustic pressure parameters: 1 - panel of acoustic pressure; 2 - panel presenting working changes; 3 - panel of analyser 
lated tests, the factors recognised as statistically significant are as follow $[7,8]$ :

- welding method;

- sheet grade and thickness;

- welding current;

- filler wire diameter;

- oxygen and carbon dioxide contents in shielding gas mixture.

An additional function of the module is the diagram-based presentation of comparative test results for various configurations of welding process parameters. It is possible to select the precise configuration of the above-named welding parameters.

\section{Conclusion}

The measurement-analytical system for assessing noise emitted during making welded structures enables the monitoring and recording of acoustic pressure levels in individual production centres (welding work stations) as well as the monitoring and recording of technological welding conditions. The system is provided with the analytical-advisory module for correlating welding conditions and noise levels. The combination of its measuring and recording functions with the analytical-advisory module concerning the making of welded structures and acoustic conditions enables the control of manufacturing processes (welding and mechanical processes) as well as the acoustic control of the work environment aimed to comply with hygienic standards of occupational noise. The system has been provided with the universal (in terms of welding process applications in various sectors) and entirely innovative database of acoustic pressure levels for various welding methods. The base has been developed for selected welding methods and current-voltage parameters commonly used industrial practice. The database used in the analytical-advisory module is based on test results focused on acoustic pressure levels for numerous combinations of welding method-base material-filler metal-shielding gas-current-voltage parameters-filler wire feed rate.

The measurement-analytical system is a solution enabling the technological and acoustic monitoring of individual production steps as well as making it possible to implement modifications of technological conditions aimed to reduce the exposure of

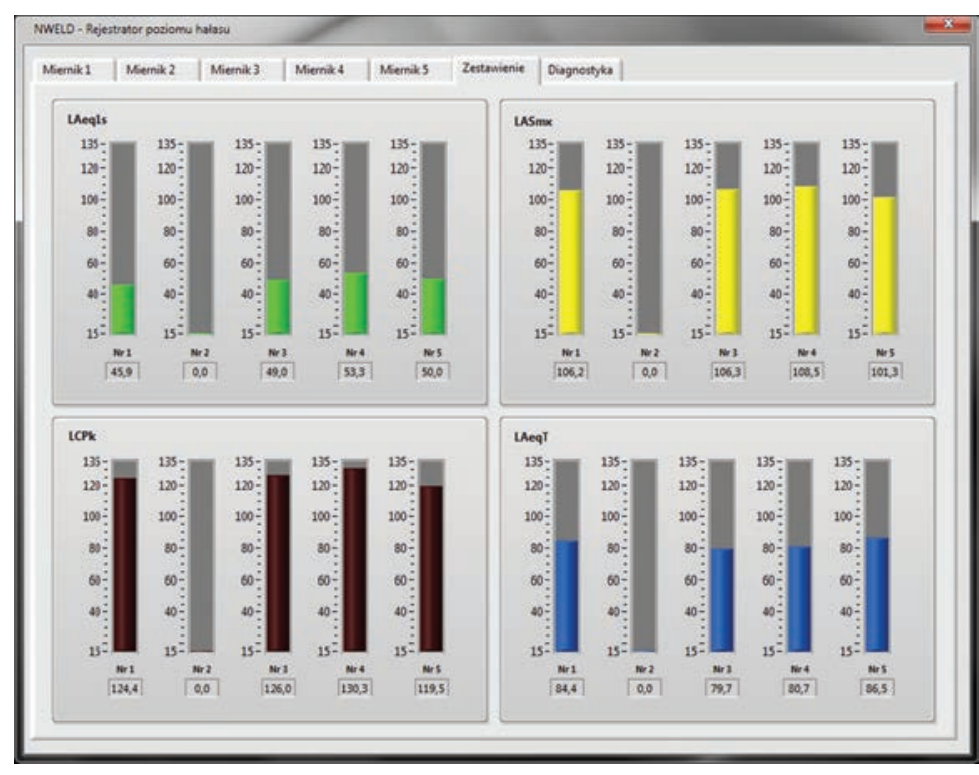

Figure 5. Bookmark List of noise level monitor software

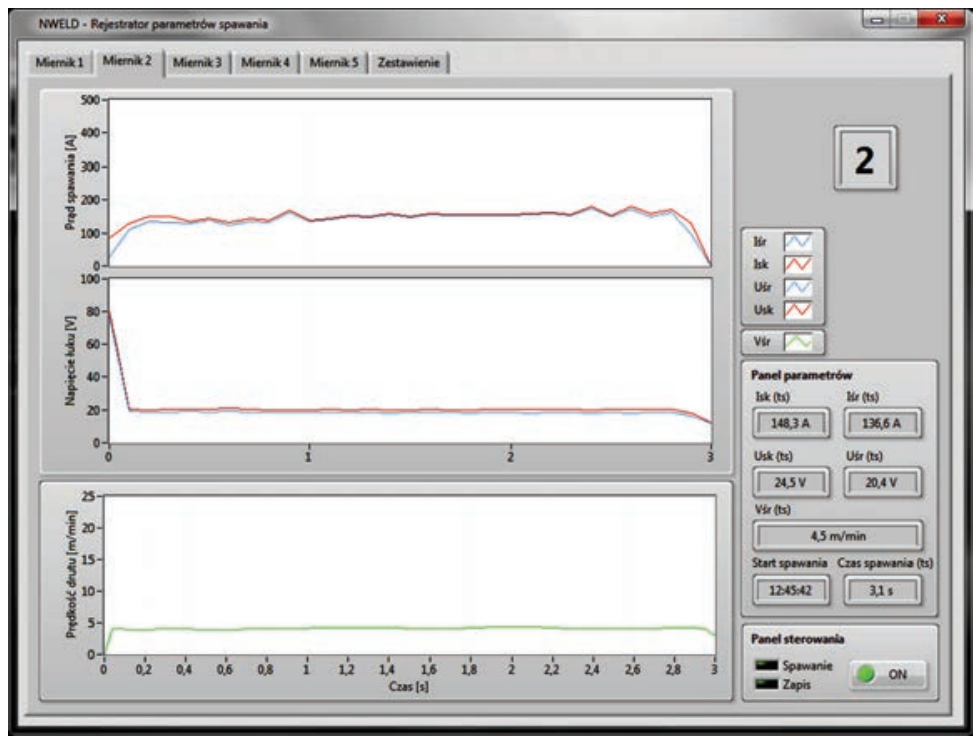

Figure 6. Main window of welding parameter monitor software

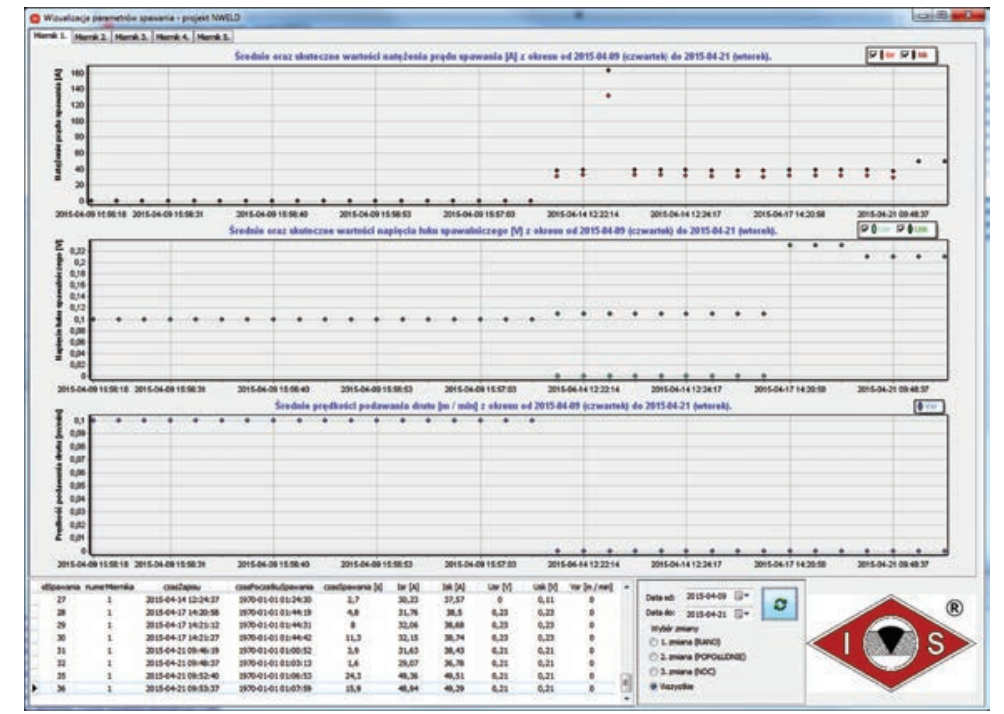

Figure 7. Main window of software for visualisation of welding process-related data 


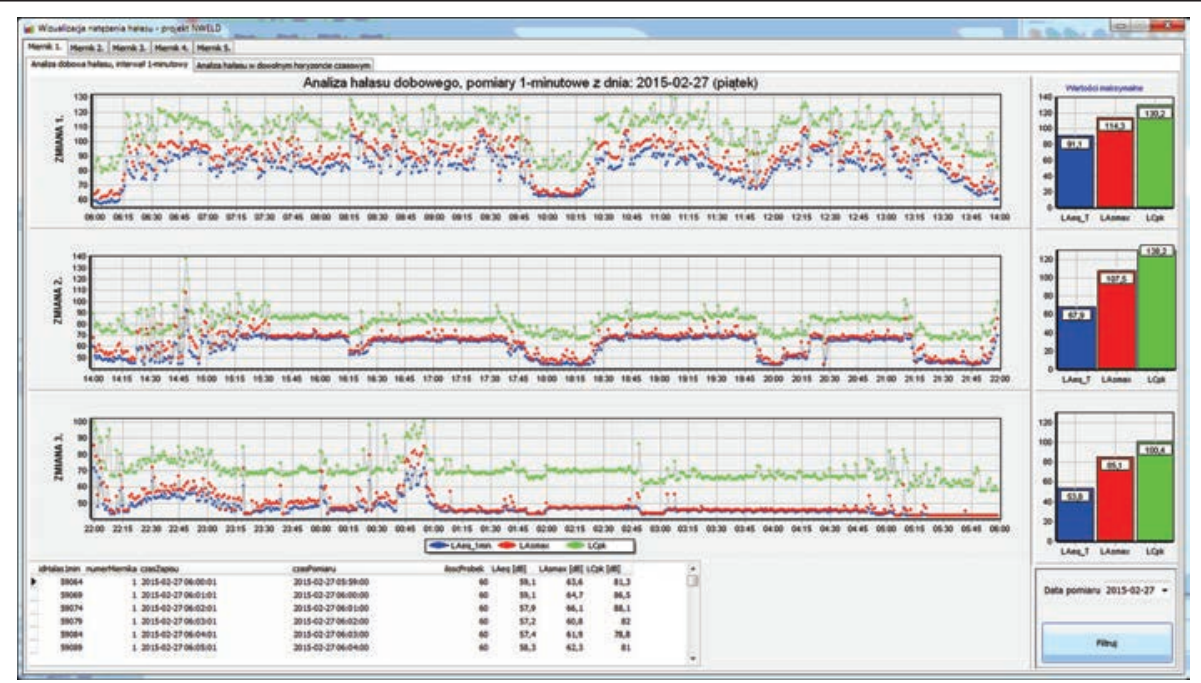

Figure 8. Main window of programme for visualisation of data concerning noise intensity

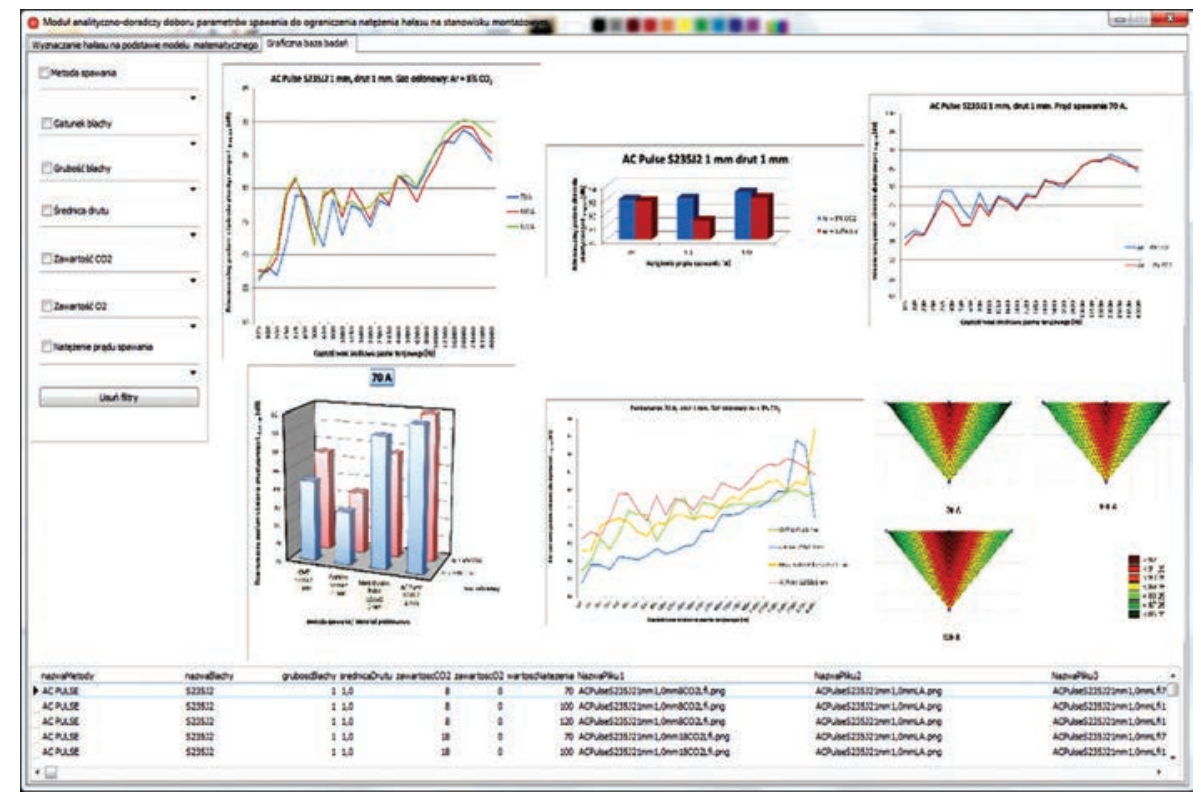

Figure 9. Analytical-advisory module for correlating welding parameters and noise levels $[1,7,8]$

workers to noise. The use of the system when making welded structures is an important move aimed at the prevention of hazards affecting workers' health. In future, such an initiative is bound to improve work conditions and increase work efficiency.

1. Badania i opracowanie systemu pomiarowo-analitycznego dla oceny poziomu dźwięku emitowanego przy wytwarzaniu konstrukcji spawanych / J. Matusiak, J. Wyciślik, L. Szubert [et al.] // Report of project INNOTECH, 2013-2015.

2. Noergaard T. Embedded systems architecture: A comprehensive guide for engineers and programmers / T. Noergaard. Amsterdam: Elsevier, 2005.

3. Szubert L. System rejestracji parametrów elektrycznych procesu spawania dla wielu stanowisk produkcyjnych / L. Szubert, P. Skoczewski, M. Welcel // Res. Report of Institute of Welding ST-284 (Fc-89), 2010.
4. Szubert L. Rozbudowa możliwości systemu monitorowania procesu spawania. Opracowanie prototypu głowicy pomiarowej do rejestracji kluczowych parametrów spawania dla urządzeń spawalniczych typu MIG/MAG / L. Szubert, P. Skoczewski, M. Welcel // Res. Report of Institute of Welding ST-323 (Fd-125), 2013.

5. Stroustrup B. Programowanie. Teoria i praktyka z wykorzystaniem C++ / B. Stroustrup. - Gliwice: Helion, 2010.

6. Wysoko wydajne MySql. Optymalizacja, archiwizacja, replikacja / B. Schwartz, P. Zaitsev [et al.]. — Gliwice: Helion, 2009.

7. Experimental tests on the effect of gas-shielded arc welding technological conditions on sound level / J. Matusiak, P. Szłapa, J. Wyciślik [el al.]. // Biuletyn Instytutu Spawalnictwa. - 2014. - № 5. - P. 159-172, http://bulletin.is.gliwice.pl/index.php?go $=$ current\&ebis=2014_05_22).

8. Hałas przy spawaniu łukowym w osłonie gazów / J. Matusiak, J. Wyciślik, P. Szłapa [et al.] // Hutnik - Wiadomości hutnicze. - 2015. - № 3. - P. 202-211. 